\title{
Analysis of Heat Transfer Characteristics by Materials in Closed Conditions Using Acrylic Hemisphere ( I ): Comparison of Interior Finishing Materials ${ }^{1}$ (
}

\author{
Seung Min $\mathrm{YANG}^{2} \cdot$ Hyun Jae $\mathrm{LEE}^{2} \cdot \operatorname{Seog}$ Goo KANG ${ }^{2, \dagger}$
}

\begin{abstract}
Global warming has increased interest in reducing greenhouse gas emissions. And a policy has effort to reduce energy consumption as a greenhouse gas reduction plan. In Korea, $25 \%$ of total energy is consumed in the building sector. In order to reduce energy consumption of buildings, it is possible to expand the utilization of wood as a structural material or thermal insulation materials with low thermal conductivity. It is also reported that when used as an interior finishing material, the energy consumption of the building is reduced by up to $7 \%$ by insulation performance. In this study, the heat transfer characteristics and the heat capacity were compared according to the three type of finishing materials(cement, paulownia coreana, medium density fiberboard) normally used as indoor finish materials. Through this study, most of the heat transfer volumes are transferred in the form of radiant heat, and the result was derived from the highest amount of energy and heat transfer in the use of paulownia coreana. When indoor finishing materials are used as wood, it is deemed that energy efficiency inside the building will be improved.
\end{abstract}

Keywords: heat conduction, heat convection, heat radiation, low density timber

\section{INTRODUCTION}

Interest in reducing greenhouse gas emissions is rising around the world to prevent global warming and climate change. And policies including reduced use of fossil fuels have been proposed as a plan to reduce greenhouse gases (Forsberg et al., 2004; Frank et al., 2005). Since an agreement regarding a new climate regime was adopted at the $21^{\text {st }}$ Conference of the Parties of the UNFCCC for the Paris Agreement in December 2015, most of the participating countries have proposed voluntary greenhouse gas emissions targets; the Republic of Korea has proposed to reduce greenhouse gas emission by $37 \%$ below Business As Usual (BAU) levels by 2030 (IPCC, 2007; Kim et al., 2013).

The government of South Korea announced 2030

${ }^{1}$ Date Received September 2, 2019, Date Accepted March 6, 2020

2 Deparment of Biobased Materials, College of Agriculture and Life Science, Chungnam National University, Deajeon 34134, Republic of Korea

† Corresponding author: Seog-goo KANG (e-mail: lachesis@cnu.ac.kr, ORCID: 0000-0002-2440-7070) 
Expansion Strategies for New Energy Industries in November 2015 to participate in global efforts to achieve greenhouse gas emissions targets and to actively respond to the paradigm shift in the global energy market (Jeong, 2015).

"Zero-Energy Buildings" has been presented as the business model for the construction sector among the 8 primary new energy business areas. Energy consumed in the buildings sector in Korea constitutes $25 \%$ of the total energy, and low energy efficient building systems cost 17 trillion Korean won or more annually (Yu et al., 2015; Jang et al., 2019; Chang et al., 2015). As a result, thermal insulation performance criteria for buildings prescribed in "Energy Saving Design Criteria for Buildings" have become stricter and require a heat transfer coefficient of $0.150 \mathrm{~W} / \mathrm{m}^{2} \cdot \mathrm{K}$ (for multi-family housing, exterior walls, Central 1 Region)(Kim et al., 2015).

Following the change in this criterion, insulation materials or construction materials with low thermal conductivity are gaining increasing attention for their energy saving effects in buildings (Pang et al., 2017). Thermal conductivities of stone, bricks, and concrete are $1-2 \mathrm{~W} / \mathrm{m} \cdot \mathrm{K}, 0.4-0.8 \mathrm{~W} / \mathrm{m} \cdot \mathrm{K}$, and $0.15-2.5 \mathrm{~W} / \mathrm{m} \cdot \mathrm{K}$, respectively; wood has a thermal conductivity of $0.1-0.2$ $\mathrm{W} / \mathrm{m} \cdot \mathrm{K}$ and is known to be the structural material used in construction with the lowest thermal conductivity (Park et al., 2012).

The Intergovernmental Panel on Climate Change (IPCC) has stated that the life expectancy for a reinforced concrete building is 50 years, whereas that of a wood building is 75 years, when climate change is considered. Using mature trees as construction materials and planting new trees where the mature trees are removed can maximize the effects of carbon dioxide reduction in the atmosphere (Kang et al., 2010). Wood is becoming a widely utilized construction material for its carbon fixation effects that reduce greenhouse gases and for its low conductivity that improves the insulation performance of buildings (Kang, et al, 2017; Seo, et al., 2017; Özcan et al, 2019; Jang et al., 2017). Additionally, a previous study has shown that the energy consumption of a building decreases by $7 \%$ or more when wood with low thermal conductivity is used as the interior finishing material (Kim, 2013), which confirms that the energy consumption of a building is affected by the type of interior finishing material. While a previous study has investigated energy consumption of a building and indoor combustion characteristics of wooden interior finishing materials (Son et al., 2014), this research aims to compare and analyze the heat transfer characteristics of 3 types of widely used interior finishing materials: mortar cement, wood (low density Paulownia coreana), and medium density fiber board (MDF).

\section{MATERIALS and METHODS}

\subsection{Testing materials}

3 types of interior finishing materials, i.e., mortar cement, Paulownia coreana, and MDF, were selected and used in this research in order to analyze insulation and heat transfer characteristics in closed conditions made by an acrylic hemisphere. Samples with dimensions $18 \mathrm{~mm}$ (thickness) $\times 200 \mathrm{~mm}$ (width) $\times 200 \mathrm{~mm}$ (length) were manufactured, and the properties of the materials are shown in Table 1. Moisture content, density when completely dried, and thermal conductivity were measured and used in this research as basic data.

Table 1. Properties of specimen

\begin{tabular}{cccc}
\hline & $\begin{array}{c}\text { Moisture } \\
\text { content }(\%)\end{array}$ & $\begin{array}{c}\text { Density } \\
\left(\mathrm{g} / \mathrm{cm}^{3}\right)\end{array}$ & $\begin{array}{c}\text { Thermal Conductivity } \\
(\mathrm{W} / \mathrm{m} \cdot \mathrm{K})\end{array}$ \\
\hline \hline $\begin{array}{c}\text { Mortar } \\
\text { Cement }\end{array}$ & 1.46 & 2.19 & 0.157 \\
$\begin{array}{l}\text { Paulowni } \\
\text { a coreana }\end{array}$ & 6.87 & 0.26 & 0.067 \\
MDF & 9.16 & 0.53 & 0.328 \\
\hline
\end{tabular}


Analysis of Heat Transfer Characteristics by Material in the Closed Conditions Using Acrylic Hemisphere( I ): Comparison of Interior Finishing Materials

\subsubsection{Mortar cement}

Mortar cement powder was obtained from company $\mathrm{H}$ located in Gyeongsangnam-do in the Republic of Korea. A cement product designed for household use that does not require mixing with sand was used in this research. A cement piece with dimensions of 18 $\mathrm{mm}$ (thickness) $\times 200 \mathrm{~mm}$ (width) $\times 200 \mathrm{~mm}$ (length) was created using a form with the corresponding dimensions, and it was cured for a week before being used in this research.

\subsubsection{Paulownia coreana}

The density of Paulownia coreana, hereinafter referred to as Korean paulownia, ranges from 0.15 to 0.3 , which is lower than other wood products and is responsible for its low thermal conductivity. Its insulation performance is 1.5 times greater than those of other high-density wood products, and it boasts a very low contraction rate in applications and a high resistance to decay and wood-destroying insects (Moon, 2019). Additional advantages of Korean paulownia include a facile painting process due to the lack of resin. Korean paulownia was selected for its significantly lower density than that of mortar cement and MDF. Glued laminated wood made of Korean paulownia was obtained from a domestic company, W, and cut into an $18 \mathrm{~mm}$ (thickness) $\times 200 \mathrm{~mm}$ (width) $\times 200 \mathrm{~mm}$ (length) piece and used in this research.

\subsubsection{MDF}

MDF obtained from a domestic company, $\mathrm{P}$, was cut into an $18 \mathrm{~mm}$ (thickness) $\times 200 \mathrm{~mm}$ (width) $\times$ $200 \mathrm{~mm}$ (length) piece and used in this research.

\subsection{Experimental methods}

\subsubsection{Fabrication of a mock-up for analysis of heat transfer characteristics}

A mock-up was created to analyze heat transfer characteristics of different interior finishing materials. The mock-up contained two compartments: a closed space where the sunlight was the sole light source (hereinafter referred to as "light source space") and another closed space without a light source where the heat that passed through the interior finishing material was transferred to the indoor air (hereinafter referred to as "lightless space"). An $18 \mathrm{~mm}$ (thickness) $\times 200$ $\mathrm{mm}$ (width) $\times 200 \mathrm{~mm}$ (length) piece made of mortar cement, MDF, or glued laminated Korean paulownia, manufactured as described in Section 2.1, was installed at the center of a mock-up as shown in Fig. 1 to represent an interior finishing material. Birch plywood with a thickness of $3 \mathrm{~mm}$ was used to create a space with

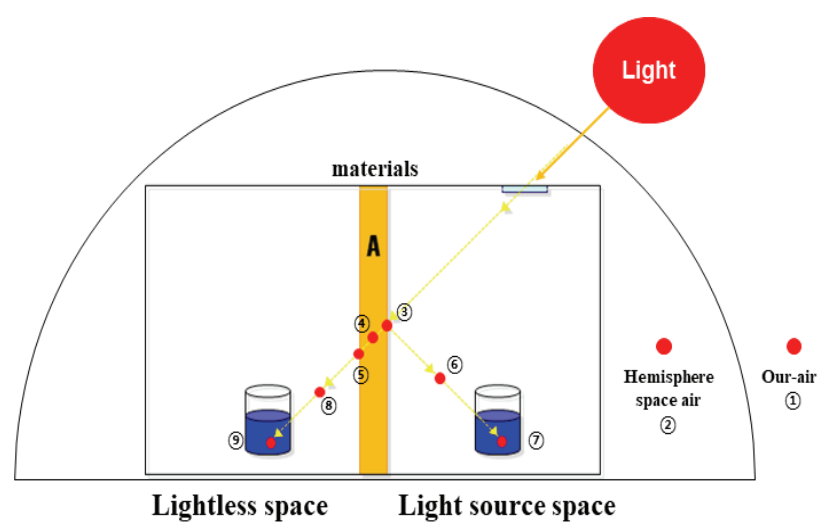

Fig. 1. Experimental model and sensor location and detail minetic diagram. 
dimensions of $200 \mathrm{~mm}$ (length) $\times 200 \mathrm{~mm}$ (width) $\times$ $200 \mathrm{~mm}$ (height) on each side of the interior finishing material. The mock-up was fully enclosed and had overall dimensions of $424 \mathrm{~mm}$ (length) $\times 260 \mathrm{~mm}$ (width) $\times 260 \mathrm{~mm}$ (height). A $30 \mathrm{~mm} \times 30 \mathrm{~mm}$ square hole was cut on top of the light source space and covered with a $3 \mathrm{~mm}$ thick transparent acrylic sheet to allow penetration of sunlight into the space. In order to prevent heat loss through the exterior walls, the birch plywood box was insulated using Isopink compressed Styrofoam with 20 thickness and a polyurethane foam adhesive.

A glass beaker (diameter: $60 \mathrm{~mm}$, height: $70 \mathrm{~mm}$, weight: $63.7 \mathrm{~g}$, and thermal conductivity: $1.022 \mathrm{~W} / \mathrm{m} \cdot{ }^{\circ} \mathrm{C}$ ) containing $200 \mathrm{~g}$ of water was sealed with Parafilm and placed in each space. The beakers were positioned at a height of $5 \mathrm{~cm}$ above the floor of the mock-up using an insulation material. K-type thermocouple temperature sensors were installed using adhesive tapes in a total of 9 locations as shown in Fig. 1 to measure temperature changes in the mock-up: the outside air (1), the air inside the dome (2), a point exposed to the sunlight on the surface of the interior finishing material (3), the midpoint of the finishing material (4)), a point on the opposite surface of the material along the light path (5), the air within each space (two locations-6), (8)), and the water (two locations-(7), (9)). In order to minimize potential effects of the outside air, the mock-up was placed inside a transparent acrylic dome with a diameter of $900 \mathrm{~mm}$ and a thickness of $9 \mathrm{~mm}$.

The mock-up was installed outdoors in Chungnam National University such that the light source space faced towards the south. Temperature changes were measured as a function of elapsed time for 2 days, starting from 10 a.m. on September 2, 2018, and measurements were made every 10 minutes using a thermal data logger (BTM-4208SD, Lutron). The amount of heat transferred through the interior material sample via conduction was calculated based on the surface temperatures measured on both sides of the sample; the amount of heat transferred from the sample surface to the air (through conduction, convection, and radiation) was calculated using the equations shown in Table 2 based on the measured temperatures (Lee, et al., 2009).

The convection heat transfer coefficient was calculated according to $h_{\text {conv }}=\frac{k}{L_{c}} \times N_{u} \times A_{\text {surf }}$, in which $k$ denotes the temperature-dependent thermal conductivity (atmosphere: $0.02699 \mathrm{~W} / \mathrm{m} \cdot \mathrm{K}$ ), and $L_{c}$ denotes the characteristic length. In order to obtain the coefficient value, the Rayleigh number, $R_{a}$, and the Nusselt Number, $N_{u}$, were calculated by the equations below, in which $g$ denotes gravitational acceleration $\left(9.8 \mathrm{~m} / \mathrm{s}^{2}\right)$, and $P_{r}$ denotes the Prandtl Number $(0.7241$ at an air temperature of $45^{\circ} \mathrm{C}, 0.7282$ at an air temperature of $30^{\circ} \mathrm{C}$ ).

Table 2. Thermal circuit for transfer mode

\begin{tabular}{|c|c|}
\hline Transfer mod & Amount of heat transferred \\
\hline Conduction & $\begin{array}{l}Q_{\text {cond }}=\Delta Q / \Delta t=k_{25{ }^{\circ} \mathrm{C}} \times A \times \Delta T / L \\
k_{25{ }^{\circ} \mathrm{C}}: \text { thermal conductivity of atmosphere at } \\
\quad 25^{\circ} \mathrm{C} \text { (Table 1) } \\
A \quad: \text { total cross sectional area of conducting } \\
\quad \text { surface } \\
\Delta T: \text { temperature difference } \\
\mathrm{L} \quad: \text { length of conducting surface }\end{array}$ \\
\hline Convection & $\begin{aligned} & Q_{\text {conv }}=h_{\text {conv }} \times A_{\text {surf }} \times \Delta T \\
& h_{\text {conv }}: \text { convection heat transfer coefficient } \\
& A_{\text {surf }}: \text { surface area } \\
& \Delta T: \text { temeprature difference }\end{aligned}$ \\
\hline Radiation & $\begin{aligned} & Q_{\text {radi }}=\sigma \times \epsilon \times A_{\text {surf }}\left(T_{1}^{4}-T_{2}^{4}\right) \\
& \sigma \quad: \text { Stefan-Boltzman constant }(5.669 \times 10-8) \\
& \epsilon \quad: \text { emissivity of materials } \\
& \text { (mortal cement : } 0.94, \text { Paulownia } \\
&\text { coreana : } 0.9, \text { MDF : } 0.85) \\
& A_{\text {surf }} \quad: \text { surface area } \\
& T_{1} \quad: \text { temperature of sample contact surface } \\
& T_{2} \quad: \text { temperature of space atmosphere }\end{aligned}$ \\
\hline
\end{tabular}


Analysis of Heat Transfer Characteristics by Material in the Closed Conditions Using Acrylic Hemisphere( I ): Comparison of Interior Finishing Materials

$$
\begin{aligned}
& R_{a}=G_{a} \times P_{r}=\frac{g \times \beta\left(T_{\text {surf }}-T_{\text {envr }}\right) \times L_{c}^{3}}{v^{2}} \times P_{r} \\
& N_{u}=0.27 R_{a}^{1 / 4}
\end{aligned}
$$

The water placed inside the mock-up is to simulate the human body, which is consisted of at least $70 \%$ water. Temperature changes in the water based on a function of elapsed time were measured to evaluate the effects on a human body residing inside a building. The heat capacities of water and a glass beaker were calculated using the equation shown below.

$$
Q=m c \Delta T=(m c \Delta T)_{\text {water }}+(m c \Delta T)_{v i a l}
$$

$m$ : mass of water and glass beaker

$c$ : heat capacity (water: $4.18 \mathrm{~kJ} / \mathrm{kg}$, beaker: $0.84 \mathrm{~kJ} / \mathrm{kg}$ ) $\triangle T:$ temperature change of water and glass beaker

\section{RESULTS and DISCUSSION}

In this research the greenhouse effect is simulated using an acrylic hemisphere, and differences in heat capacities based on the type of interior finishing materi- als had been made through heat transfer modes and changes in water temperature. The temperatures of the ambient air and the air inside the acrylic dome during the exposure of the mock-up are shown in Fig. 2.

\subsection{Comparison of heat transfer modes in the light source space and heat capacity of the glass beakers}

The modes of heat transfer and the heat capacity of the glass beakers are calculated based on the difference between the temperature of the interior finishing material and the air temperature, and the temperature changes of the glass beakers in the light source space where the material was exposed to the sunlight. The temperature difference, defined as the material temperature minus the air temperature, is shown in Fig. 3 for the light source space. The maximum difference between the temperature measured at the spot exposed to the sunlight and the air temperature is 2.1 ${ }^{\circ} \mathrm{C}$ for Korean paulownia and $2.2{ }^{\circ} \mathrm{C}$ for MDF, when the elapsed times are 23 hours and 34 hours, respectively. While their differences between the maximum and minimum temperatures are similar, Korean paulownia

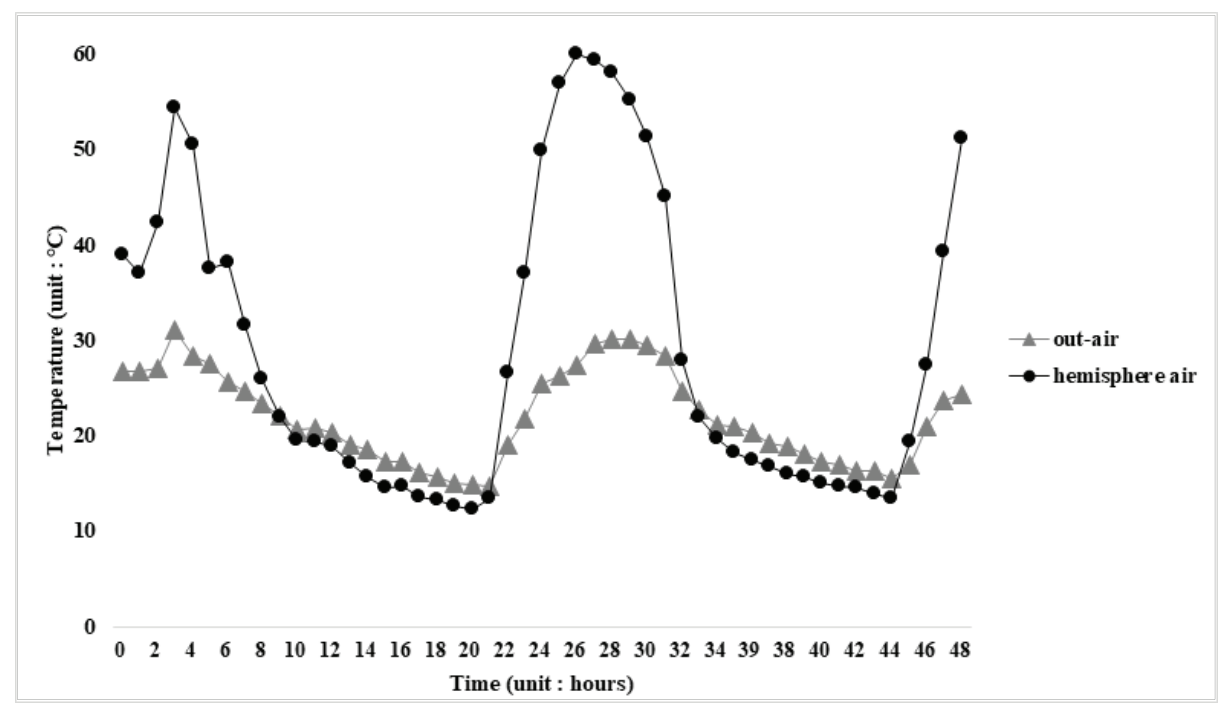

Fig. 2. Temperature of our-air and acrylic hemisphere air during 2 days. 
displays a temperature profile that is lower than that of MDF in overall according to Fig. 3. The cement sample exhibits a $4.6{ }^{\circ} \mathrm{C}$ maximum difference after 24 hours, which is approximately $2.4{ }^{\circ} \mathrm{C}$ larger than that of the wood and MDF samples. The overall trends in temperature change as a function of elapsed time are similar for Korean paulownia and concrete, but the MDF shows a spike after 24-25 hours are elapsed, which indicates that the surface temperature of the material increases more than the air temperature of the light source space. The air temperature inside the light source space increased between 20 hours (6 a.m.) and 25 hours (11 a.m.), which is similar to the changes of the air temperatures outside and inside the dome as shown in Fig. 2, due to light absorption in the hemispheric space. The MDF finishing material exhibited a higher surface temperature than the air temperature after 25 hours elapsed, and it was reversed after 1 hour. These results are closely related to the heat capacity and thermal conductivity characteristics of the materials. While temperature differences were originally expected to decrease in the order of Korean paulownia, MDF, and cement, it is hypothesized that the MDF used in
Table 3. Comparison of amount of heat transferred for three materials in light source space during 9 hours

\begin{tabular}{cccc}
\hline & Concrete & $\begin{array}{c}\text { Korean } \\
\text { Paulownia }\end{array}$ & $\begin{array}{c}\text { Medium Density } \\
\text { Fiberboard }\end{array}$ \\
\hline \hline \multirow{2}{*}{ Conduction } & $0.026 \mathrm{~W}$ & $0.006 \mathrm{~W}$ & $0.006 \mathrm{~W}$ \\
& $(1.18 \%)$ & $(1.22 \%)$ & $(1.34 \%)$ \\
Convection & $0.829 \mathrm{~W}$ & $0.167 \mathrm{~W}$ & $0.136 \mathrm{~W}$ \\
& $(37.36 \%)$ & $(36.06 \%)$ & $(29.63 \%)$ \\
Radiation & $1.364 \mathrm{~W}$ & $0.291 \mathrm{~W}$ & $0.316 \mathrm{~W}$ \\
& $(61.46 \%)$ & $(62.72 \%)$ & $(69.03 \%)$ \\
Total & $2.219 \mathrm{~W}$ & $0.464 \mathrm{~W}$ & $0.458 \mathrm{~W}$ \\
\hline $\begin{array}{c}\text { Total energy } \\
\text { transferred to } \\
\text { vial and water }\end{array}$ & $18.852 \mathrm{~kJ}$ & $19.980 \mathrm{~kJ}$ & $19.646 \mathrm{~kJ}$ \\
\hline
\end{tabular}

this study resulted in a greater amount of radiation due to reflection from the surface coating, therefore displaying different results from the cement and Korean paulownia.

Heat transfer modes and energy efficiency in the light source space are calculated for the time range where the temperature differences (surface temperature - air temperature) are the largest, i.e., between 24 hours (10 a.m.) and 33 hours (7 p.m.), and summarized in Table 3. Heat is transferred from the surface that is exposed to the sunlight to the air by radiation, convection, and

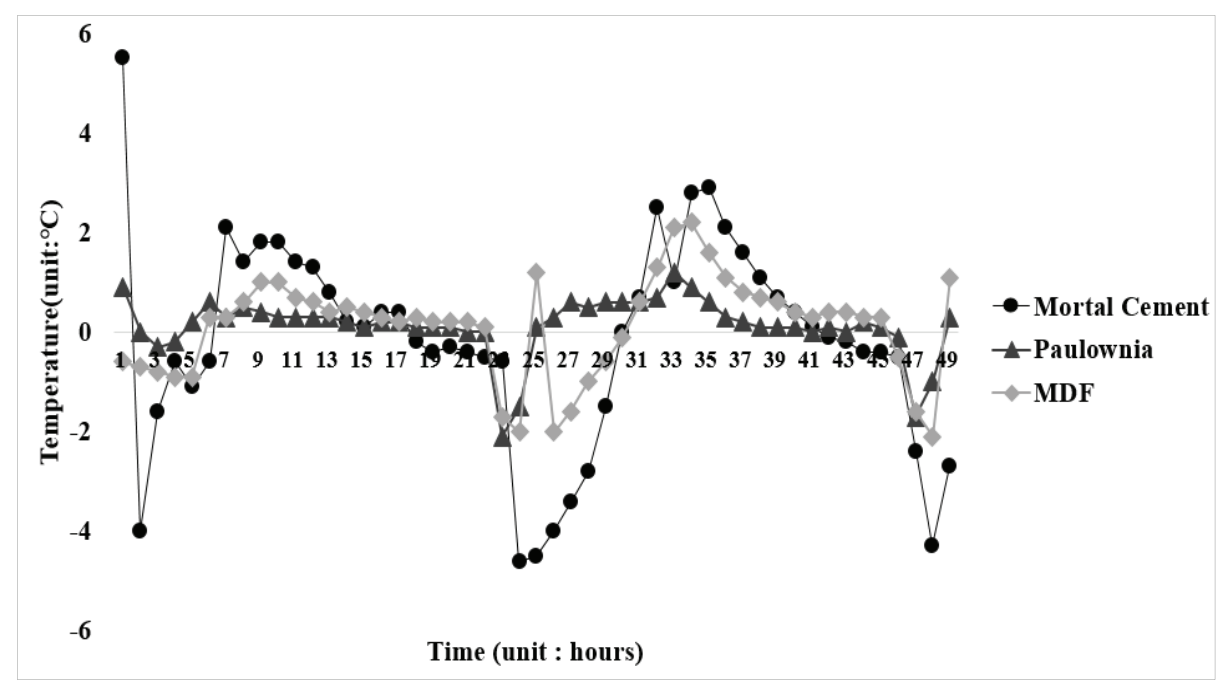

Fig. 3. Temperature Difference between surface of material and air in Light source space. 
Analysis of Heat Transfer Characteristics by Material in the Closed Conditions Using Acrylic Hemisphere( I ): Comparison of Interior Finishing Materials

conduction, at contributions of $61-70 \%, 29-38 \%$, and approximately $1 \%$, respectively. The amount of heat that is transferred from the material's surface to the air is found to decrease in the order of cement $(2.219$ W), Korean paulownia (0.464 W), and MDF (0.458 $\mathrm{W})$, which indicates that the concrete transfers approximately 4.7 times more heat compared with the wood and MDF.

Convection heat represents the amount of heat that is transferred from the material surface to the air through air circulation in the mock-up chamber, and it differs by $0.66-0.69 \mathrm{~W}$, depending on the material. More amount of heat is transferred by convection in the order of cement, MDF, and Korean paulownia. This result suggests that the use of wood, which has a lower density, leads to a greater amount of convection heat transfer, i.e., a greater amount of heat circulated inside the space, compared with higher density materials.

Radiation heat represents heat that is absorbed by the material and emitted back, and it shows a greater variation among the materials than conduction or convection. More amount of heat is transferred by radiation in the order of Korean paulownia, MDF, and cement, with the maximum difference among the three materials being approximately $1 \mathrm{~W}$. Because the difference of $1 \mathrm{~W}$ is still relatively small, we could not confirm the correlation between the density, thermal conductivity of materials and heat transfer by conduction, convection, and radiation in the light source space.

The amount of energy that is transferred to the water contained in the glass beaker shows a difference of approximately $1 \mathrm{~kJ}$ among the three materials used. The largest amount of energy is transferred to the water when Korean paulownia is used, and the smallest when concrete is used, approximately $18.9 \mathrm{~kJ}$.

\subsection{Comparison of heat transfer modes (between the interior finishing material and the air) and heat capacity of the glass beakers in the lightless space}

Modes of heat transfer and heat capacity of the glass beakers are calculated during the elapsed time range of 24-33 hours, where it had a greatest temperature difference between all three interior finishing materials and the air, and the greatest changes in water temperature. The temperature differences between the materials and

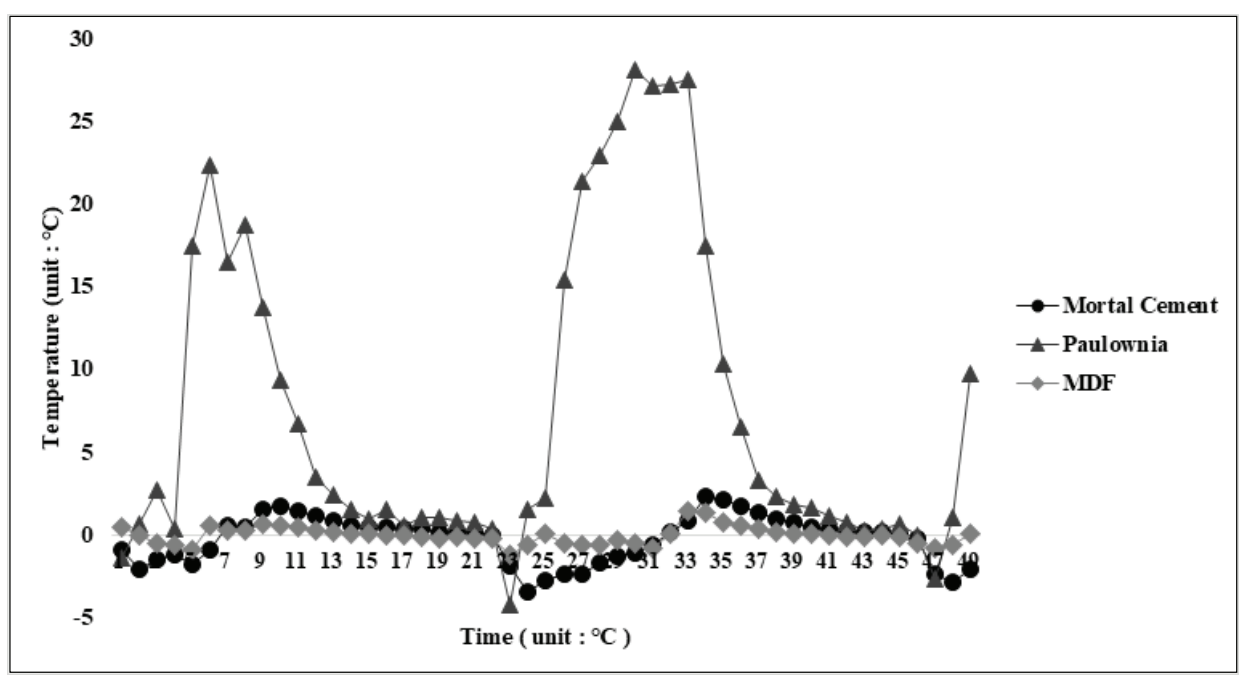

Fig. 4. Temperature Difference between surface of material and air in Lightless space. 
the air in the lightless space are shown in Fig. 4. Korean paulownia exhibits the largest difference, $28{ }^{\circ} \mathrm{C}$, whereas the concrete and MDF exhibit smaller differences that are equal to or less than $8{ }^{\circ} \mathrm{C}$. These temperature differences are closely related to the differences in the amount of heat transferred from the materials to the air. The results suggest that heat transfer from the concrete and MDF to the air occurs fast, whereas Korean paulownia tends to store the heat within the material rather than transferring to the air. This can be also inferred from the air temperature measurements in the lightless space after 33 hours, which was measured to be $27.1{ }^{\circ} \mathrm{C}$ for Korean paulownia, $48.3{ }^{\circ} \mathrm{C}$ for the mortar cement, and $50.8{ }^{\circ} \mathrm{C}$ for the MDF. This result is attributable to the thermal conductivity of wood; it can be concluded that the use of the wood with low thermal conductivity leads to an efficient temperature control of the space due to a large amount of heat absorbed in the sample even if a large amount of heat is transferred through the sample. However, further studies about the effects of physical properties such as surface coating of MDF on heat transfer is necessary to understand why the MDF results in a higher air temperature than the mortar cement along with the higher thermal conductivity of MDF.

Modes of heat transfer and energy efficiency in the lightless space are summarized in Table 4. The heat in the lightless space is transferred from the interior material to the air by radiation (51-68\%), convection (30-47\%), and conduction (approximately 1\%).

The total amount of heat transferred from the sample surface to the air decreases in the order of Korean paulownia $(15.365 \mathrm{~W})$, cement $(0.8 \mathrm{~W})$, and MDF $(0.315 \mathrm{~W})$; heat transferred by the concrete is approximately two times greater than that of MDF, and heat transferred by Korean paulownia is approximately 20 times greater than that of the concrete. The heat which passed through the sample and reached the opposite surface is transferred to the air in the lightless
Table 4. Comparison of amount of heat transferred for three materials in Lightless space during 9 hours

\begin{tabular}{cccc}
\hline & Cement & $\begin{array}{c}\text { Korean } \\
\text { Paulownia }\end{array}$ & $\begin{array}{c}\text { Medium Density } \\
\text { Fiberboard }\end{array}$ \\
\hline \hline \multirow{2}{*}{ Conduction } & $\begin{array}{c}0.011 \mathrm{~W} \\
(1.35 \%)\end{array}$ & $\begin{array}{c}0.149 \mathrm{~W} \\
(0.97 \%)\end{array}$ & $\begin{array}{c}0.005 \mathrm{~W} \\
(1.47 \%)\end{array}$ \\
& $0.273 \mathrm{~W}$ & $7.310 \mathrm{~W}$ & $0.095 \mathrm{~W}$ \\
Convection & $(34.18 \%)$ & $(47.57 \%)$ & $(30.12 \%)$ \\
& $0.516 \mathrm{~W}$ & $7.91 \mathrm{~W}$ & $0.251 \mathrm{~W}$ \\
Radiation & $(64.48 \%)$ & $(51.46 \%)$ & $(68.41 \%)$ \\
\hline Total & $0.8 \mathrm{~W}$ & $15.365 \mathrm{~W}$ & $0.315 \mathrm{~W}$ \\
\hline
\end{tabular}

Total energy

transferred to $19.103 \mathrm{~kJ} \quad 19.855 \mathrm{~kJ} \quad 19.186 \mathrm{~kJ}$

vial and water

space partly by conduction, and heat transferred by conduction is observed to have minimal difference among all three materials, which is similar to the results obtained from the light source space.

Convection heat represents the amount of heat that is transferred from the material surface to the air through air circulation within the mock-up, and the maximum difference among the three materials is $7 \mathrm{~W}$. It is observed that more heat is transferred by conduction in the order of MDF, cement, and Korean paulownia, which is similar to the results obtained from the light source space. While a comparison of convection heat transferred by cement and MDF is difficult due to their small difference of less than $1 \mathrm{~W}$, convection heat for Korean paulownia, which has a low density, is 35 times greater than that for the MDF and cement. This result suggests that the use of wood which has a low density leads to a greater amount of heat transferred by convection, i.e., a greater amount of heat circulated inside the space, compared with higher density materials.

Radiation heat represents heat absorbed by the material and emitted back, and it shows a greater variation among the materials than conduction or convection. More amount of heat is transferred by 
Analysis of Heat Transfer Characteristics by Material in the Closed Conditions Using Acrylic Hemisphere( I ): Comparison of Interior Finishing Materials

radiation in the order of $\mathrm{MDF}$, cement, and Korean paulownia, with a maximum difference among the three materials of approximately $14 \mathrm{~W}$. This result suggests that materials with lower density and lower thermal conductivity lead to a greater amount of heat transferred by radiation.

The amount of energy used to heat the water contained in the glass beaker shows a difference of approximately $1 \mathrm{~kJ}$ among the three materials used. The largest amount of energy is transferred to the water when Korean paulownia material is used, and the smallest when the concrete is used, which is approximately $19.1 \mathrm{~kJ}$.

\section{CONCLUSIONS}

The heat transfer characteristics and heat capacity of interior finishing materials are compared in this research. Three types of commonly used interior finishing materials are selected for comparison: cement, Korean paulownia, and MDF.

1. The light source space did not show significant difference between the amount of energy and heat transfer in each material, which suggests that heat reflected from the material surfaces does not affect the temperature increase of the space.

2. It is observed that more amount of heat is transferred from the material to the air in the lightless space in the order of MDF, cement, and Korean paulownia; significant differences are observed in the amount of heat loss among the three materials. The fact that the amounts of heat transferred through conduction from the MDF and cement are different by less than $1 \mathrm{~W}$ suggests that the conduction heat is proportional to the thermal conductivity and density of the material. Therefore, it is concluded that better energy efficiency can be obtained by using materials with low thermal conductivity and low density as interior finishing materials.
3. The amount of energy that is transferred to the water contained in the glass beakers is the highest when Korean paulownia is used, approximately $19.9 \mathrm{~kJ}$, in both the light source space and lightless space, and the corresponding values for the cement and MDF are similar to one another, $19.1 \mathrm{~kJ}$ and $19.2 \mathrm{~kJ}$, respectively. If the water in the beakers represents a human body, it can be concluded that a resident is likely to feel warmest in a room finished with Korean paulownia.

Radiation constitutes the major mode of heat transfer in this experiment. Korean paulownia which has a low density exhibits the greatest amount of energy and heat transfer, and therefore, it is the most optimal material for energy efficiency. The use of interior finishing material wood is expected to increase energy efficiency inside the building.

\section{ACKNOWLEDGMENT}

This work was supported by research fund of Chungnam National University.

\section{REFERENCES}

Chang, Y.S., Kim, S.K., Shim, K.B., Lee, S.J., Han, Y.J., Park, Y.G., Yeo, H.M. 2015. Assessment on Thermal Transmission Property of Wall Through a Scaled Model Test. Journal of the Korean Wood Science and Technology 43(6): 889-894.

Forsberg, A., von Malmborg, F. 2004. Tools for environmental assessment of the built environment, Building and Environment, 39(2): 223-228.

Frank, T. 2005. Climate change impacts on building heating and cooling energy demand in Switzerland, Energy and Buildings, 37(11): pp. 1175-1185.

IPCC, Climate Change 2007. Synthesis Report, An Assessment of the Intergov-ernmental Panel on Climate Change, 2007. 
Jang, J.H., Lee, M., Kang, E.C., Lee, S.M. 2017. Characteristics of Low Density Fiberboards for Insulation Material with Different Adhesives (I): Thermal Insulation Performance and Physical Properties. Journal of the Korean Wood Science and Technology 45(3): 360-367.

Jang, S.S., Lee, H.W. 2019. Thermal Resistance and Condensation in the Light-frame Timber Wall Structure with Various Composition of Insulation Layers. Journal of the Korean Wood Science and Technology 47(5): 553-542.

Jeong. H. 2015. The EU`s Efforts into achieving the goal of "2030 frameworks for Climate and Energy Policies": With focus on the EU ETS and CCS. Journal of Common Market Studies 33(2): 377-409. Kang, K.S., Cha, J.H., Yun, Y.C., Park, M.J., Park, J.S. 2010. Analysis of Life Cycle Greenhouse Gas Emissions and Energy Use of Han-Green HouseComparison with Reinforced Concrete Hose-. Proceeding of the Korean Forest Society pp. 503506.

Kang, Y.J., Lee, J.H., Lee, H.Y., Kim, S.M. 2017. Heating and Cooling Energy Demand Evaluating of Standard Houses According to Layer Component of Masonry, Concrete and Wood Frame Using PHPP. Journal of the Korean Wood Science and Technology 45(1): 1-11.

Kim, S.J., Park, J.S. 2015. Insulation Details and Energy performance of Post-Beam Timber House for Insulation Standards. Journal of the Korean Wood Science and Technology 43(6): 876-883.

Kim, S. M. 2013. Application of Wood and Wooden Architecture Order to Save Construction Energy. Review of architecture and building science 57(4): 13-16.

Kim, S.W., Yu, S.G., Seo, J.K., Kim, S.M. 2013. Thermal Performance of Wooden Building Envelope by Thermal Conducticity of Structural Members.
Journal of the Korean Wood Science and Technology 41(6): 515-527.

Lee, H.H., Bender, D.A. 2009. Far Infrared Emissivity of Wood Material-Comparing the Three Heat Transfer Modes of Wood Box and Aluminum Box-. Journal of the Korean Wood Science and Technology 37(5): 440-450.

Moon, S.O. 2019. A Study on Developing Eco-friendly Paulownia Wooden products by Laser SystemsFocusing on Adapting Paulownia burnt by the Traditional Korean Technique-. Journal of the Korean furniture Society 30(4): 427-436.

Özcan, M.C., Korkmaz, M. 2019. Determination of Relationship between Thermal and Mechanical Properties of Wood Material. Journal of the Korean Wood Science and Technology 47(4): 408-417.

Pang, S.J., Lee, S.J., Jeon, G.Y. 2017. Insulation Saving Effect for Korean Apartment House Using CrossLaminated Timber (CLT). Journal of the Korean Wood Science and Technology 45(6): 846-856.

Park, J.M., Kim, D.H., Suh, D.J. 2012. Recent Research Trends for Green Building Thermal Insulation Materials. Clean Technology 18(1): 14-21.

Seo, J.G., Jeong, S.G., Kim, S.M. 2017. Thermal Bridge and Heat Transfer Analysis for Each Part in Residential Building According to Construction of Wood-based Finishing Material. Journal of the Korean Wood Science and Technology 45(3): 343-359.

Son, D. W., Kang, S. G. 2014. Combustion Properties of Woods for Indoor Use( I ). Journal of the Korean Wood Science and Technology 42(6):675-681.

Yu, J. Y., Shin, S. E., Cho, D. W. 2015. An Analysis on Heating Energy Use and Economic Evaluation of Passive Apartments Compared to Existing Apartments-Focused on the Zero Carbon Green Home-. Journal of Real Estate Analysis 1(1k): 111-132. 
Analysis of Heat Transfer Characteristics by Material in the Closed Conditions Using Acrylic Hemisphere( I ): Comparison of Interior Finishing Materials

\author{
APPENDIX \\ (Korean Version)

\section{아크릴 반구를 이용한 밀폐 조건에 따른 재료별 열 이동 특성 분석(I): 실내마감재 종류에 따른 비교}

초록 : 지구온난화로 인한 온실가스 배출 감소에 대한 관심도가 증가하고 있으며, 이 중 온실가스 감축 계획으로 에너지 소비 감소 계획이 제안되고 충족을 위한 건축물이 열관류율 기준이 강화되었다. 한국에서는 소비되는 전체 에너지 중 약 $25 \%$ 는 건축부문에 사용되고 있으며 건물 에너지 소비량 감소를 위한 열전도율이 낮은 건축자재 또는 단열재 개발이 요구되고 있으며, 열전도율이 낮은 목재의 활용 사례도 증가하고 있다. 또한 내부 마감재로 사용될 경우 건물 에너지 소비가 최대 $7 \%$ 까지 감소된다 는 선행연구 결과를 바탕으로 본 연구에서는 일반적으로 실내마감재로 사용되는 3가지 유형의 마감재(시멘트, 오동나무, MDF) 에 따라 열전달특성 및 열용량을 비교하였다. 본 연구를 통하여 열 이동은 복사열의 형태로 전달되며 오동나무 마감재 사용 시 에너지량과 열전달량이 가장 많은 결과로 실내 마감재로 목재 사용 시 건물 내부의 에너지 효율을 향상시킬 것으로 판단된다.

\title{
1. 서 론
}

전 세계적으로 지구온난화와 기후변화 방지를 위해 온실가스 배출 감축에 대한 관심도가 높아지고 있으며, 온실가스 감축 방안으로 화석연료 소비 절감 등의 정책이 제안되고 있다(Forsberg et al., 2004; Frank et al., 2005). 2015년 12월 파리협정으로 제 21 차 기후변화협약 당사국총회에서 신기후체제 대응에 관한 합의문이 채택되어 대부분 당사국들은 자발적인 온실가스 감축 목표를 제시하였으며, 우리나라는 2030년까지 온실가스 배출을 배출 전망치(Business As Usual, BAU) 대비 $37 \%$ 감축하기 로 제시하였다(IPCC, 2007; Kim et al., 2013).

온실가스 배출 감축 목표를 달성하기 위하여 정부는 국제적인 온실가스 감축 노력에 동참함과 동시에, 세계 에너지시장의 패러다임 변화에 적극 대응하기 위하여 2015년 11월「2030 에너지신산업 확산전략」을 발표하였다(Jeong, 2015).

에너지신사업 8 대 사업 중 건물부문을 대상으로 하는 사업 모델로는 「제로에너지빌딩」 이 제시되었으며, 국내 건축물 분야에 소비되는 에너지는 총 에너지의 $25 \%$ 이며, 저에너지 효율 건물시스템으로 인해 매년 17 조 이상의 비용이 낭비되고 있다(Yu et al., 2015; Jang et al., 2019; Chang et al., 2015). 이로 인해「건축물 에너지절약 설계기준」 중 건축물 단열성능 기준이 열관류율이 $0.150 \mathrm{~W} / \mathrm{m}^{2} \cdot \mathrm{K}$ (공동주택, 외벽, 중부 1지역 기준) 까지 강화되었다(Kim et al., 2015).

열관류율 강화로 건물 에너지 절감 효과를 가지는 열전도율이 낮은 단열재 또는 건축자재에 대한 관심도가 높아지고 있다(Pang et al., 2017). 이 중 건축구조재로 석재 1 2 W/m.K, 벽돌 $0.4 \sim 0.8 \mathrm{~W} / \mathrm{m} \cdot \mathrm{K}$, 콘크리트 $0.15 \sim 2.5 \mathrm{~W} / \mathrm{m} \cdot \mathrm{K}$ 의 열전도율을 나타내며, 목재는 $0.1 \sim 0.2 \mathrm{~W} / \mathrm{m} \cdot \mathrm{K}$ 의 열전도율로 건축 구조재 중 가장 낮은 열전도율을 가진 재료로 알려져 있다(Park et al., 2012).

기후변화에 관한 정부 간 협의체(IPCC)에 따르면 기후변화 고려 시 철근콘크리트 건물의 기대수명은 50 년이며 목조건물의 기대수명은 75 년으로 약 25 년 수명이 더 길다고 발표하였다. 성숙한 나무를 벌채해서 건축재료를 사용하고, 벌채한 자리에 새로운 나무를 심는다면 대기 중의 이산화탄소 저감효과를 극대화할 수 있다(Kang et al., 2010). 온실가스 감축의 방법 중 하나로 탄소고정효과를 가진 목재와 건축물의 단열성능 증가를 위하여 열전도율이 낮은 건축자재인 목재를 활용성이 높아지고 있다(Kang et al., 2017; Seo et al., 2017; Özcan et al., 2019; Jang et al., 2017). 또한, 낮은 열전도율을 가진 목재를 실내 마감 재료로 사용 시 건물에너지 소요량이 최대 7\% 이상 감소한다(Kim, 2013)는 선행연구 결과를 통해 목재실내마감재에 따라 건물에너지 소요량에 영향을 미친다는 것을 확인하였다. 그러나 목재 실내 마감 재료에 대한 연구는 건물에너지 소요량과 실내 연소특성(Son et al., 2014)에 대한 연구가 진행되어있어 본 연구에서는 일반적으로 실내마감재로 사용되고 있는 시중의 몰탈 시멘트, 목재(저비중 오동나무), $\mathrm{MDF}$ 의 3가지 실내마감재 종류에 따른 열 이동 특성을 비교 분석하고자 한다.

\section{2. 재료 및 방법}

2.1. 공시재료

본 연구에서는 반구를 이용한 밀폐 조건에서의 실내 마감재 종류에 따른 단열 및 열 이동특성 분석을 위하여 실내마감재 
중 시중 몰탈 시멘트, 오동나무, MDF 3가지를 선정하여 사용하였다. $18 \mathrm{~mm}$ (Thickness) $\times 200 \mathrm{~mm}$ (Width) $\times 200 \mathrm{~mm}$ (Length)크기로 제작하였으며 이때 사용한 재료 특성은 Table 1과 같으며 함수율, 전건 밀도, 열전도율을 측정하여 본 연구의 기초데이터로 사용하였다.

\subsection{1. 몰탈 시멘트}

경남 소재의 $\mathrm{H}$ 사로부터 분양받은 몰탈 시멘트 분말은 가정용 시멘트로 모래 혼합 없이 사용가능한 제품을 사용하였다. $18 \mathrm{~mm}$ (Thickness) $\times 200 \mathrm{~mm}$ (Width) $\times 200 \mathrm{~mm}$ (Length) 규격으로 제작하기 위해 거푸집을 제작하여 사용하였으며, 두께 $18 \mathrm{~mm}$ 로 제작한 후 1 주일간의 양생기간을 거쳐 제작된 제품을 본 연구에 사용하였다.

\subsection{2. 오동나무 (Paulownia coreana)}

오동나무는 비중이 $0.15 \sim 0.3$ 으로, 다른 목재에 비하여 비중이 낮아 열전도율 또한 낮은 수종이다. 비중이 높은 목재보다 약 1.5 배의 높은 단열성능을 발휘하며, 실제 사용시 수축율 또한 매우 낮으며, 부패에도 강하며 목재 해충에 대한 저항성을 가지고 있다(Moon, 2019). 또한, 수지나 송진이 없으므로, 도장이 용이하다는 장점을 가지고 있다. 몰탈 시멘트, MDF와 비중차 이가 큰 오동나무를 본 재료로 선정하였고, 국내의 $\mathrm{W}$ 사로부터 분양받은 오동나무 집성판을 $18 \mathrm{~mm}$ (Thickness) $\times 200 \mathrm{~mm}$ (Width) $\times 200 \mathrm{~mm}$ (Length)의 크기로 재단하여 본 연구에 사용하였다.

\subsection{3. $\mathrm{MDF}$}

국내의 P사로부터 분양받은 두께 $18 \mathrm{~mm}$ 의 MDF (Medium Density Fiber Board)를 $18 \mathrm{~mm}$ (Thickness) $\times 200 \mathrm{~mm}$ (Width) $\times 200 \mathrm{~mm}$ (Length)로 재단하여 본 연구에 사용하였다.

\section{1. 실험방법}

2.2.1. 열 이동 특성 분석을 위한 Mock-up 제작

본 연구에서는 광원(햇빛)만 투과되는 밀폐 공간 내에 실내마감재 종류 따라 광원이 있는 공간과 실내마감재를 통해 투과된 열이 전달된 미광원 공간에서 실내마감재에 종류에 따라 대기로 전달되는 열 이동특성을 분석하고자 목업 제작을 실시하였다. 2.1 의 공시재료에서 제조된 $18 \mathrm{~mm}$ (Thickness) $\times 200 \mathrm{~mm}$ (Width) $\times 200 \mathrm{~mm}$ (Length) 크기의 몰탈 시멘트, MDF, 오동나무 집성판을 이용하였으며 실내마감재를 기준으로 양쪽에 $200 \mathrm{~mm}$ (Length) $\times 200 \mathrm{~mm}$ (Wideth) $\times 200 \mathrm{~mm}$ (Hight)의 공간을 구성하기 위하여 자작나무 $3 \mathrm{~mm}$ 합판을 사용하여 제작하였다(Fig. 1). 이때 목업의 전체 크기는 $424 \mathrm{~mm}$ (Length) $\times 26$ $\mathrm{mm}$ (Wideth) $\times 26 \mathrm{~mm}$ (Hight)이며 밀폐되게 제작한 후 태양열이 들어올 수 있도록 가로 $30 \mathrm{~mm}$ 크기의 정사각형을 상부에 타공 후 $3 \mathrm{~mm}$ 두께의 투명 아크릴을 부착하였다. 이때, 벽체 외부로의 열 이동에 따른 손실을 막기 위하여 제작된 자작나무 합판 상자 표면에 두께 20T의 아이소핑크 압축 스티로폼과 우레탄폼 접착제를 이용하여 단열 시공하여 제작하였다.

양쪽의 내부 공간에 물 $200 \mathrm{~g}$ 유리비커(유리비커 지름 : $60 \mathrm{~mm}$, 높이 : $70 \mathrm{~mm}$, 무게 : $63.7 \mathrm{~g}$, 열전도도 : $1.022 \mathrm{~W} / \mathrm{m}{ }^{\circ} \mathrm{C}$ )에 담은 후 파라필름으로 마감한 후 사용하였다. 물의 설치 위치는 유리비커 하단부에 단열재를 부착하여 목업 바닥으로부터 $5 \mathrm{~cm}$ 띄어 설치하였다. 제작된 목업 내 온도변화 측정을 위하여 외부 대기(1), 반구 내 대기(2), 실내 마감재에 광원 접촉점(3), 중앙점(4), 광원 미접촉점(5), 양측 공간의 대기(2지점-6), 8), 설치된 물 내(2지점-7), (9)로 총 9지점에 K타입의 열전대 온도 센서를 천면 점착 테이프를 사용하여 부착하였으며, 부착 위치는 Fig. 1과 같다. 제조된 목업의 외기에 의한 영향을 제거하기 위하여 지름 $900 \mathrm{~mm}$ 에 두께 $9 \mathrm{~mm}$ 의 투명 아크릴 반구 공간 내에 제작된 목업을 설치하여 본 연구를 진행하였다.

제조된 목업은 충남대학교 내 옥외에 광원공간이 남향방향이 되도록 설치하였으며 2일(2018년 9월 2일 오전 10시 시작)간 시간 경과에 따른 온도 변화를 측정하였다. 이때 온도 측정 주기는 10분으로 Thermal data logger (BTM-4208SD, Lutron)를 이용하여 측정하였다. 측정된 온도결과를 이용하여 시료의 양쪽 표면의 온도를 통해 전도 열량과 시료 접촉면으로부터 공간 대기로 열 이동량(전도, 대류, 복사)은 Table 2의 계산식을 이용하여 산출하였다(Lee et al., 2009).

열 이동 중 대류열은 대류열 전달계수를 계산하여 대입하였으며, $h_{\text {conv }}=\frac{k}{L_{c}} \times N_{u} \times A_{s u r f}$ 와 같이 정의된다. $k$ 는 온도에 따른 열전도도(atmosphere : $0.02699 \mathrm{~W} / \mathrm{m} \cdot \mathrm{K}$ )이며, $L_{c}$ 는 대표길이이다. 이를 구하기 위해 $R_{a}$ (Rayleigh Number) 값과 $N_{u}$ (Nusselt Number)의 값은 아래의 식에 의해 산출할 수 있으며, $g$ 는 중력가속도 $\left(9.8 \mathrm{~m} / \mathrm{s}^{2}\right), P_{r}$ 은 Prandtl Number(0.7241 at $45^{\circ} \mathrm{C}$ of mean air temperature, 0.7282 at $30^{\circ} \mathrm{C}$ of mean air temperature) 이다. 
Analysis of Heat Transfer Characteristics by Material in the Closed Conditions Using Acrylic Hemisphere( I ): Comparison of Interior Finishing Materials

$$
\begin{gathered}
R_{a}=G_{a} \times P_{r}=\frac{g \times \beta\left(T_{\text {surf }}-T_{\text {envr }}\right) \times L_{c}^{3}}{v^{2}} \times P_{r} \\
N_{u}=0.27 R_{a}^{1 / 4}
\end{gathered}
$$

Mock-up 내 설치된 물은 $70 \%$ 이상의 물로 구성된 인체로 가정하였으며 건물 내부에 상주하는 인체에 미치는 영향 평가를 위한 요소로 시간 경과에 따른 온도 변화를 측정하였다. 그 결과는 아래의 식에 의거하여 물과 유리비커의 열용량을 산출하였다.

$$
\begin{aligned}
& Q=m c \triangle T=(m c \triangle T)_{w a t e r}+(m c \triangle T)_{v i a l} \\
& m: \text { 물과 유리비커의 질량 } \\
&c \quad: \text { 열용량 (water : } 4.18 \mathrm{~kJ} / \mathrm{kg}, \text { vial }: 0.84 \mathrm{~kJ} / \mathrm{kg}) \\
& \triangle T: \text { 물과 유리비커의 온도 변화 }
\end{aligned}
$$

\section{3. 결과 및 고찰}

본 연구에서는 아크릴 반구를 이용한 온실효과 simulation을 통한 실내 마감재 종류에 따라 재료별 열전달 방식의 차이와 물의 온도변화를 통하여 열용량을 비교하였다. 이때 목업 노출 기간 동안의 대기 및 아크릴 반구 내 대기의 온도는 Fig. 2 와 같다.

\section{1. 광원 공간의 열전달 방식 및 유리병 열용량 비교}

실내 마감재 종류에 따른 광원 공간(자재 표면에 햇빛 접촉)의 실내마감재-대기온도의 차이와 유리병의 물 온도 변화를 통하여 열전달 방식과 유리병의 열용량을 산출하였다. 광원 공간의 실내마감재와 대기의 온도차는 Fig. 3 와 같으며, 실내마감 재의 광원 접촉 점-대기의 최대 온도 차이는 오동나무 $2.1^{\circ} \mathrm{C}\left(23\right.$ 시간 경과), $\mathrm{MDF} 2.2^{\circ} \mathrm{C}$ (34시간 경과)로 경과시간에는 차이가 있지만 최대-최소 온도 차이는 유사하지만 Fig. 3에 따르면 MDF 보다는 오동나무가 낮은 온도 그래프를 나타냈다. 콘크리트 $4.6^{\circ} \mathrm{C}\left(24\right.$ 시간 경과)로 오동나무, $\mathrm{MDF}$ 보다 약 $2.4^{\circ} \mathrm{C}$ 높은 온도차이를 나타냈다. 시간 경과에 따른 오동나무와 콘크리트는 동일한 경향을 나타내지만, $\mathrm{MDF}$ 는 24 25시간 때 광원 공간의 대기보다 재료 표면의 온도가 높아지는 결과를 나타냈다. 이는 Fig. 2의 외부와 반구 내 온도변화 결과와 동일하게 20시간(오전 8시)에서 25시간(오전 11시)까지 반구 내로 광원의 흡수에 의해 광원 공간 내 대기온도가 상승하였다. $\mathrm{MDF}$ 마감재는 25 시간 경과 시 마감재의 광원 접촉점의 온도가 높아졌으나 1 시간 후인 26 시간 경과 시 대기의 온도가 높아진 결과를 나타냈다. 이는 재료의 열용량과 열전도도 특성과 밀접한 관련이 있으며, 오동나무, $\mathrm{MDF}$, 시멘트 순으로 높은 온도 차이를 예측할 수 있으나, 본 연구에 사용된 $\mathrm{MDF}$ 는 $\mathrm{MDF}$ 표면 코팅에 의한 반사로 태양복사 에너지에 의해 온도가 높아져 콘크리트와 오동나무와는 다른 결과를 나타낸 것으로 판단된다.

최대 온도 차이(표면온도-대기온도)를 나타낸 24(10시)-33(19시)시간의 광원 공간의 열 전달방식 및 에너지 효율을 산출하 였으며 그 결과는 Table 3 과 같다. 햇빛이 접촉된 표면에서 대기로 전달된 열은 $61-70 \%$ 복사열, 29-38\% 대류열, 약 $1 \%$ 는 전도열의 형태로 열이 전달되었다. 시료 접촉 표면으로부터 대기로 전달된 총 열은 시멘트 $(2.219 \mathrm{~W})>$ 오동나무 $(0.464$ $\mathrm{W})>\mathrm{MDF}(0.458 \mathrm{~W})$ 순으로 나타났으며, 콘크리트의 경우 오동나무와 $\mathrm{MDF}$ 에 비하여 약 4.7배 높은 열을 전달하였다.

대류열의 경우 재료 표면에 가해진 열 중 Mock-up 내부에서 공기와 함께 순환되는 열의 양을 나타낸 것이며, 대류열의 경우 재료별로 0.66-0.69 W 정도 차이를 나타냈다. 이는 시멘트 < $\mathrm{MDF}<$ 오동나무 순으로 높은 열전달을 나타냈으며, 저비중인 목재를 사용한 경우 고비중 재료에 비하여 공간 내에 대류되는 열의 양, 즉 내부에 순환되는 열의 양이 많은 것으로 판단할 수 있다.

복사열의 경우 재료 표면에 가해진 열 중 재료 내에 흡수되었다가 다시 방출됨으로써 이동되는 열로, 전도나 대류에 비해 재료마다의 큰 차이를 나타냈다. 오동나무 < $\mathrm{MDF}<$ 시멘트 순으로 나타났으며, 약 $1 \mathrm{~W}$ 의 차이를 나타냈으며, 이 결과는 $1 \mathrm{~W}$ 차이로 크지 않기 때문에, 광원공간에서는 전도, 대류, 복사와 재료의 밀도, 열전도율 간의 관계성은 확인할 수 없었다. 유리비커의 물의 온도를 높이는데 사용된 에너지의 값은 약 $1 \mathrm{~kJ}$ 정도 차이를 나타냈으며, 오동나무 재료를 사용 시 가장 많은 에너지를 받았으며, 콘크리트의 경우 약 $18.9 \mathrm{~kJ}$ 의 에너지로 가장 적은 에너지를 받은 것으로 나타났다.

3.2. 미광원공간(실내마감재의 광원 투과점-미광원 대기)의 열전달 방식 및 유리병 열용량 비교 실내 마감재 종류에 따른 미광원 공간의 실내마감재-대기온도의 차이와 유리병의 물 온도 변화 중 최대 온도 차이를 나타낸 
24-33시간에 열전달 방식과 유리병의 열용량을 산출하였다. 미광원 공간의 실내마감재와 대기의 온도차는 Fig. 4와 같으며, 그 결과 오동나무 재료 사용 시 최대 $28^{\circ} \mathrm{C}$ 의 온도 차이를 나타냈으며, 콘크리트와 $\mathrm{MDF}$ 는 $8^{\circ} \mathrm{C}$ 이하로 낮은 온도 차이를 나타냈다. 이는 실내마감재 접촉점으로부터 대기로 전달된 열의 차이와 밀접한 관련이 있으며 콘크리트, $\mathrm{MDF}$ 는 대기로 열전달 속도가 빠르며, 오동나무는 대기로 열전달보다는 재료 내에 열에너지를 저장하는 결과를 도출할 수 있다. 이는 미광원 대기온도(33시간 경과)인 오동나무 $27.1^{\circ} \mathrm{C}$, 몰탈 시멘트 $48.3^{\circ} \mathrm{C}, \mathrm{MDF} 50.8^{\circ} \mathrm{C}$ 의 온도 측정 결과로도 유추할 수 있다. 이는 목재의 열전도율과 관계가 있으며, 열전도율이 낮은 목재를 사용하면 시료를 통해 전달되는 에너지양은 많으나 시료 내부에 흡수열이 많아 공간의 온도조절에 효율적인 것으로 판단할 수 있다. 그러나 $\mathrm{MDF}$ 의 경우 열전도율은 낮으나 몰탈 시멘트 보다 높은 대기온도를 나타낸 결과에 대해서는 $\mathrm{MDF}$ 의 표면 코팅 등과 같은 물성에 따른 열전달과의 추가적인 연구가 필요할 것으로 판단된다.

미광원공간의 열 전달방식 및 에너지 효율의 결과는 표 4 와 같으며 미광원공간의 실내 마감재 표면에서 대기로 전달된 열은 $51-68 \%$ 복사열, $30-47 \%$ 대류열, 약 $1 \%$ 는 전도열의 형태로 열이 전달되었다.

시료 접촉 표면으로부터 대기로 전달된 총 열은 오동나무 $(15.365 \mathrm{~W})>$ 시멘트 $(0.8 \mathrm{~W})>\mathrm{MDF}(0.315 \mathrm{~W})$ 순이며, $\mathrm{MDF}$ 에 비하여 콘크리트는 약 2 배, 콘크리트에 비해 오동나무는 약 20 배 높은 열을 전달하였다. 시료 표면을 통과한 열은 목업 내부의 공기로 전도되며, 전도열의 경우 재료 간에 미미한 차이를 나타냈으며, 이는 앞선 광원공간과 동일한 결과를 나타냈다.

대류열의 경우 재료 표면에 가해진 열 중 목업 내부에서 공기와 함께 순환되는 열의 양을 나타낸 것이며, 대류열의 경우 재료별로 최대 $7 \mathrm{~W}$ 정도 차이를 나타냈다. 이는 $\mathrm{MDF}<$ 시멘트 < 오동나무 순으로 높은 전도열을 나타냈으며, 광원공간과는 유사하나, 시멘트와 $\mathrm{MDF}$ 는 대류열이 $1 \mathrm{~W}$ 이하로 비교하기 어려우나, 저비중 목재인 오동나무는 $\mathrm{MDF}$ 와 시멘트 보다 약 35 배 높은 대류열을 나타냈다. 이는 저비중인 목재를 사용한 경우, 고비중 재료에 비하여 공간 내에 대류되는 열의 양, 즉 내부에 순환되는 열의 양이 많은 것으로 판단할 수 있다.

복사열의 경우 재료 표면에 가해진 열 중 재료 내에 흡수되었다가 다시 방출됨으로써 이동되는 열로, 전도나 대류에 비해 재료마다의 큰 차이를 나타냈다. $\mathrm{MDF}<$ 시멘트 < 오동나무 순으로 나타났으며, 약 $14 \mathrm{~W}$ 의 차이를 나타냈으며, 이 결과는 밀도가 낮고, 열전도율이 낮은 재료일수록 복사열이 많은 것으로 판단할 수 있다.

유리비커의 물의 온도를 높이는데 사용된 에너지의 값은 약 $1 \mathrm{~kJ}$ 정도 차이를 나타냈으며, 오동나무 재료를 사용시 가장 많은 에너지를 받았으며, 시멘트의 경우 약 $19.1 \mathrm{~kJ}$ 의 에너지로 가장 적은 에너지를 받은 것으로 나타났다.

\section{4. 결 론}

본 연구에서는 일반적으로 실내마감재로 사용되고 있는 시멘트, 오동나무, $\mathrm{MDF}$ 의 3 가지 실내마감재 종류에 따른 열 이동 특성과 열용량을 비교하였다.

1. 광원공간은 재료별 에너지량과 열 전달량에 큰 차이는 나타나지 않았으며, 이는 재료에서 반사열이 공간의 온도 상승에 큰 영향을 미치지 않는 것으로 판단된다.

2. 미광원공간은 실내마감재로부터 대기로 전달된 열은 $\mathrm{MDF}<$ 시멘트 < 오동나무 순으로 높았으며 재료에 따라 열 손실량에 는 큰 차이를 나타냈다. 전도열은 $\mathrm{MDF}$ 와 시멘트는 $1 \mathrm{~W}$ 도 차이가 나지 않음을 통해 전도열은 열전도도와 밀도에는 비례하 는 것으로 유추할 수 있다. 실내마감재로 사용시 열전도도와 밀도가 낮은 재료를 사용하는 것이 에너지 효율을 높일 수 있을 것으로 판단된다.

3. 광원공간과 미광원공간 내부에 설치한 유리병과 물이 받은 에너지양은 오동나무 사용시 약 $19.9 \mathrm{~kJ}$ 로 가장 높았으며, 시멘트와 MDF는 $19.1 \mathrm{~kJ}, 19.2 \mathrm{~kJ}$ 로 큰 차이를 나타내지는 않았다. 유리병과 물을 사람으로 가정할 시, 오동나무를 실내 마감재로 사용시 재실자가 가장 따뜻함을 느낄 수 있을 것으로 판단된다.

열 전달량 중 대부분은 복사열의 형태로 이동되며, 저비중인 오동나무 사용시 가장 높은 에너지양과 열전달량을 나타냈고, 에너지를 효율적으로 사용하는데 최적 재료이며, 실내 마감재료 목재를 사용할 때 건물 내부의 에너지 효율을 높일 것으로 사료된다. 